\title{
Effect of Malathion on Microbial Population, Acid and Alkaline Phosphatase Activity of Soil
}

\author{
Bonita Mahanta \\ Institutional Level Biotech Hub, Sibsagar Girls’ College, Temple Road, Sivasagar, Assam- 785640, India
}

\begin{abstract}
In this study the response of microbial populations, acid and alkaline phosphatase activities of microorganisms in garden soil after incorporation of the pesticide Malathion [S-1,2-bis(ethoxycarbonyl)ethyl O,O-dimethyl phosphorodithioate] were examined. The effect of malathion was observed over a period of ten days in three different concentrations each viz., $1 \%, 0.5 \%$ and $0.2 \%$. Total microbial count was highly affected in presence of malathion and persisted up to 7 days when the population of soil microbes was found to be highest in untreated soil sample $\left(7.55 \times 10^{6}\right.$ cells per gram of soil) followed by samples having $0.2 \%\left(6.2 \times 10^{6}\right.$ cells per gram), $0.5 \%$ $\left(1.4 \times 10^{6}\right.$ cells per gram) and undiluted concentrations $\left(0.6 \times 10^{6}\right.$ cells per gram) of the pesticide. Phosphatase activity in soil was unaffected initially (up to 3 days) and then sharply decreased on day 7 with $10.359 \mu \mathrm{g} / \mathrm{g} / \mathrm{hr}, 15.263 \mu \mathrm{g} / \mathrm{g} / \mathrm{hr}, 14.44 \mu \mathrm{g} / \mathrm{g} / \mathrm{hr}$ and $10.144 \mu \mathrm{g} / \mathrm{g} / \mathrm{hr}$ of p-nitrophenol in control, $1 \%, 0.5 \%$ and $0.2 \%$ concentrations of malathion treated soil respectively.
\end{abstract}

Keywords: Malathion, organophosphate pesticide, garden soil, microbial population, acid and alkaline phosphatase

\section{Introduction}

Soil is the unconsolidated top layer of the earth's crust, formed by mineral particles, organic matter, water, air and living organisms. It is an extremely complex and dynamic medium containing many free enzymes, immobilized extracellular enzymes and enzymes within microbial cells which forms the substratum for the growth of a wide range of microflora and microfauna. Microorganisms, including fungi and bacteria, affect chemical exchanges between roots and soil and act as a reserve of nutrients. They also secrete different chemicals which affect the soil in different ways. A wide variety of synthetically produced chemicals including insecticides, fungicides, herbicides and other pesticides are utilized in modern agriculture which on injudicious application greatly affect the soil microorganisms and soil enzymes. These functions are worthy of study because of their socio-economic as well as environmental importance. Enzymes are the organic catalyst in biological reactions without themselves being altered. Soil enzymes indicate the soil quality and play an important role in organic matter decomposition and nutrient cycling. One such enzyme, Phosphatase, is a hydrolysing enzyme that removes a phosphate group from its substrate by hydrolysing phosphoric acid mono esters into a phosphate ion and a molecule with a free hydroxyl group. A common phosphatase in many organisms is alkaline phosphatase. Alkaline phosphatase is responsible for removing phosphate groups from many types of molecules, including nucleotides, proteins, and alkaloids, called dephosphorylation. Acid phosphatase is a widely found soil enzyme, used to free attached phosphate groups from other molecules. Phosphatase enzymes are also used by soil microorganisms to access organically bound phosphate nutrients. An assay on the rates of activity of these enzymes may be used to ascertain biological demand for phosphates in the soil.

Malathion is a pesticide of relatively low human toxicity and the most commonly used organophosphate insecticide in the US [1]. It is a cholinesterase inhibitor, acts as non-systemic pesticide and acaricide with contact, stomach and respiratory action, widely used in agriculture, residential landscaping,

public recreation areas, and in public health, pest control programs such as mosquito eradication, to control many insect pests in a wide range of crops [2]. When a synthetic pesticide is released into the environment, only a small fraction of it reaches the target organism, while the remaining interferes with local metabolism or enzymatic activities, and also affects human health by entering into the food chain, which is a matter of public concern. Thus, it is required to estimate soil biological responses to the pesticides in terms of soil enzyme activities.

\section{Materials and Methods}

The soil samples were collected from the college garden on September 3, 2015. Separate plots that received no application of pesticides were used as controls. Around $20 \mathrm{~kg}$ of the soil sample was collected to a depth of $10-15 \mathrm{~cm}$ with no history of pesticide treatment.

In the laboratory, plant material and soil macrofauna were removed, and soil samples sieved and mixed and then in semi dry condition divided and put in $1 \mathrm{~kg}$ polythene bags. 10 bags of soil were kept untreated (to be used as control), the rest were treated with the pesticide of different concentrations, 3 bags each for recommended dose of the pesticide, 2 times and 5 times dilution of the recommended dose respectively. Controls, with soil only, were included within all tests.

\subsection{Dosage}

For recommended dose (T1 $=0.002 \mathrm{ml}$ per $\mathrm{ml}$ of water)

$0.6 \mathrm{ml}$ of Malathion (25\%) in $299.4 \mathrm{ml}$ of distilled water = $300 \mathrm{ml}$ of $1 \%$ Malathion

For $2 x$ diluted dose $(\mathrm{T} 2=0.0016 \mathrm{ml}$ per $\mathrm{ml}$ of water $)$

$150 \mathrm{ml}$ of $\mathrm{T} 1 \mathrm{in} 150 \mathrm{ml}$ of distilled water $=300 \mathrm{ml}$ of $0.5 \%$ Malathion

For $5 x$ diluted dose $(\mathrm{T} 3=0.0006 \mathrm{ml}$ per $\mathrm{ml}$ of water)

$60 \mathrm{ml}$ of $\mathrm{T} 1 \mathrm{in} 240 \mathrm{ml}$ of distilled water $=300 \mathrm{ml}$ of $0.2 \%$ Malathion

\section{Volume 5 Issue 3, March 2016}




\section{International Journal of Science and Research (IJSR) \\ ISSN (Online): 2319-7064 \\ Index Copernicus Value (2013): 6.14 | Impact Factor (2014): 5.611}

Where $\mathrm{T} 1$ the dose recommended for use by the farmers and $\mathrm{T} 2$ and $\mathrm{T} 3$ are dilutions made from the recommended dose of the pesticide.

The biological activity of the soil microbes and the physicochemical properties of the soil were studied and represented in the form of tables and graphs. Soil microbes from treated and control soils were grown on nutrient agar (Peptone- 10g, NaCl- 5g, Agar- 2\%, Distilled water-1000ml, pH- 7.5) media and their population count was made by dilution plate technique [3]. Phosphatase activity was measured colorimetrically by using PNPP (paranitrophenyl phosphate). Aliquots of soil sample (5gm each) were mixed with $20 \mathrm{ml}$ of paranitrophenyl phosphate $(10 \mu \mathrm{g} / \mathrm{ml})$ in culture tubes, incubated for two hours, except for the blank sample, and then centrifuged. The blank sample was mixed with PNPP and immediately centrifuged. Now from each centrifuged supernatant, $1 \mathrm{ml}$ is taken in labelled test tubes and $2 \mathrm{ml}$ of $0.1 \mathrm{~N} \mathrm{NaOH}$ is added. The absorbance of each sample is then estimated at 420nm by using a UV-visible spectrophotometer. The standard curve was prepared by taking 2, 4, 6, 8 and $10 \mu \mathrm{g} / \mathrm{ml}$ solutions of $\mathrm{p}$-nitrophenyl phosphate in tris buffer (acidic and alkaline) and the total amount of p-nitrophenol is expressed as $\mu \mathrm{g} / \mathrm{g}$ of soil per hour.

\section{Result and Discussion}

The changes in the total microbial population, alkaline and acid phosphatase activity recorded on day 0 , day 3, day 7 and day 10 have been tabulated as follows:

On day 0 , microbial population remained almost equal in treated as well as untreated soil with $7.45 \times 10^{6}$ cells per gram of soil in control soil sample, $7.2 \times 10^{6}$ cells, $7.35 \times 10^{6}$ cells and $7.15 \times 10^{6}$ cells per gram of soil in soil sample treated with recommended, 2 times diluted and 5 times diluted dosage of malathion respectively. From day 3 onwards, microbial population was highest in control soil sample with $7.35 \times 10^{6}$ cells, $7.55 \times 10^{6}$ cells and $7.65 \times 10^{6}$ cells per gram of soil on day3, day 7 and day 10 respectively, whereas it was lowest in the soil sample treated with recommended dose of malathion showing $1.5 \times 10^{6}$ cells, $0.6 \times 10^{6}$ cells and $1.5 \times 10^{6}$ cells per gram of soil on day 3, day 7 and day 10 respectively. With increase in the time interval of application of the pesticide, the microbial population decreases from day 0 to 10th day in case of treated soil. These results can be supported by several works on the effect of malathion which have been published previously by various workers. Malathion at $100-300 \mathrm{mg} / \mathrm{g}$ had specifically toxic effect on certain type of microorganisms but stimulated the growth of another types [4]-[6]. Earlier works show the inhibition percent of soil bacteria by malathion at 250ppm after 24, 48 and 72 hours to be $16 \%, 24 \%$ and $40 \%$ respectively and that of soil fungi to be $44 \%, 47 \%$ and $58 \%$ respectively [7].

Effect of malathion on alkaline and acid phosphatase activity showed similar results. On day 0 , malathion did not affect the phosphatase activity very much and the phosphatase activity was found to be same at all concentrations of the pesticide. On 3rd day also, the pesticide was not much effective on the enzyme activity. But on 7th day the activity of alkaline and acid phosphatase was found to decrease with increase in concentration of the pesticide. Finally on 10th day it was found that the activity of alkaline phosphatase increased slowly but the acid phosphatase activity of the microbes showed a further decreasing effect towards the action of malathion. This shows that malathion is slow in action, moderately persistent in soil and its effect on the enzyme activity gradually decreases after the 10th day of its application [8]-[11]. Also, the effect of different concentrations of the pesticide was not same against the acid phosphatase activity of soil microbes as they show variation during different periods of time. This is because Malathions are less effective on soil microbes and their activities [12]. In addition to that, population of phosphate solubilizing bacteria depends on different soil properties (physical and chemical properties, organic matter, and Phosphorus content) and cultural activities [13].

It was observed that the effect of the pesticides on the soil microbial population was not uniform in all cases and their effect diminished gradually after a few days. This is because several microorganisms play a major role in the breakdown or degradation of pesticides in soil. Most of the pesticides applied in the soil suppress the microbial activity in soil but are soon lost from the soil, resulting in the microbial population to rebound. Some investigations resulted in the identification of microbial isolates which are apparently responsible for the accelerated degradation of individual pesticides [14]-[16]. Most of the organophosphate and carbamate pesticides like malathion and parathion disappear more quickly than organochlorines and other pesticides [17]. The most influential bacterial strains on the acceleration of malathion degradation rate include Bacillus licheniformis, $B$. pseudomycoides and Pseudomonas aeruginosa [18].

\subsection{Dilution plate result for Malathion treated soil}




\section{International Journal of Science and Research (IJSR) \\ ISSN (Online): 2319-7064 \\ Index Copernicus Value (2013): 6.14 | Impact Factor (2014): 5.611}

Table 1: Effect of different concentrations of malathion on microbial population per gram of control and treated soil

\begin{tabular}{|c|c|c|c|c|c|}
\hline \multicolumn{2}{|c|}{$\begin{array}{c}\mathrm{DOSE} \rightarrow \\
\mathrm{TIME} \downarrow\end{array}$} & $\begin{array}{c}\text { CONTROL (number } \mathrm{x} \\
10^{6} \text { ) }\end{array}$ & $\begin{array}{c}\text { RECOMMENDED (number } x \\
10^{6} \text { ) }\end{array}$ & $\begin{array}{c}\text { 2x DILUTED (number } \\
\times 10^{6} \text { ) }\end{array}$ & $\begin{array}{c}5 \mathrm{x} \text { DILUTED (number } \mathrm{x} \\
10^{6} \text { ) }\end{array}$ \\
\hline \multirow[t]{5}{*}{ Ohr } & \multirow{2}{*}{$\begin{array}{c}\text { Number of } \\
\text { cells/gm of soil }\end{array}$} & 7.2 & 7.1 & 7.2 & 7.5 \\
\hline & & 7.7 & 7.3 & 7.5 & 6.8 \\
\hline & Mean & 7.45 & 7.2 & 7.35 & 7.15 \\
\hline & $\mathrm{SD}$ & 0.17 & 0.07 & 0.1 & 0.24 \\
\hline & Remarks & $\begin{array}{l}\text { Creamy, white, small, } \\
\text { round colonies }\end{array}$ & $\begin{array}{l}\text { Creamy, white, small, round } \\
\text { colonies }\end{array}$ & $\begin{array}{l}\text { Large, white, mycelia } \\
\text { like colonies }\end{array}$ & $\begin{array}{l}\text { Large, white, mycelia } \\
\text { like colonies }\end{array}$ \\
\hline \multirow[t]{5}{*}{ Day 3} & \multirow{2}{*}{$\begin{array}{c}\text { Number of } \\
\text { cells/gm of soil }\end{array}$} & 7 & 1.7 & 2.3 & 4.8 \\
\hline & & 7.7 & 1.3 & 3.5 & 5.2 \\
\hline & Mean & 7.35 & 1.5 & 2.9 & 5 \\
\hline & SD & 0.24 & 0.14 & 0.42 & 0.14 \\
\hline & Remarks & $\begin{array}{l}\text { Creamy, white, small, } \\
\text { round colonies }\end{array}$ & $\begin{array}{c}\text { Creamy, white, small, round } \\
\text { colonies }\end{array}$ & $\begin{array}{l}\text { Large, white, mycelia } \\
\text { like colonies }\end{array}$ & $\begin{array}{l}\text { Large, white, mycelia } \\
\text { like colonies }\end{array}$ \\
\hline \multirow[t]{5}{*}{ Day 7} & \multirow{2}{*}{$\begin{array}{c}\text { Number of } \\
\text { cells/gm of soil }\end{array}$} & 7.2 & 0.7 & 1.1 & 5.5 \\
\hline & & 7.9 & 0.5 & 1.7 & 6.9 \\
\hline & Mean & 7.55 & 0.6 & 1.4 & 6.2 \\
\hline & SD & 7.2 & 0.7 & 1.1 & 5.5 \\
\hline & Remarks & $\begin{array}{l}\text { Creamy, white, small, } \\
\text { round colonies }\end{array}$ & $\begin{array}{c}\text { Creamy, white, small, round } \\
\text { colonies }\end{array}$ & $\begin{array}{l}\text { Large, white, mycelia } \\
\text { like colonies }\end{array}$ & $\begin{array}{l}\text { Large, white, mycelia } \\
\text { like colonies }\end{array}$ \\
\hline \multirow[t]{5}{*}{ Day 10} & \multirow{2}{*}{$\begin{array}{c}\text { Number of } \\
\text { cells/gm of soil }\end{array}$} & 7.4 & 1.9 & 2.5 & 4.8 \\
\hline & & 7.9 & 1.1 & 2.7 & 3.3 \\
\hline & Mean & 7.65 & 1.5 & 2.6 & 4.05 \\
\hline & $\mathrm{SD}$ & 0.17 & 0.28 & 0.07 & 0.53 \\
\hline & Remarks & $\begin{array}{l}\text { Creamy, white, small, } \\
\text { round colonies }\end{array}$ & $\begin{array}{l}\text { Creamy, white, small, round } \\
\text { colonies }\end{array}$ & $\begin{array}{l}\text { Large, white, mycelia } \\
\text { like colonies }\end{array}$ & $\begin{array}{l}\text { Large, white, mycelia } \\
\text { like colonies }\end{array}$ \\
\hline
\end{tabular}

3.2 Alkaline phosphatase activity of Malathion treated soil

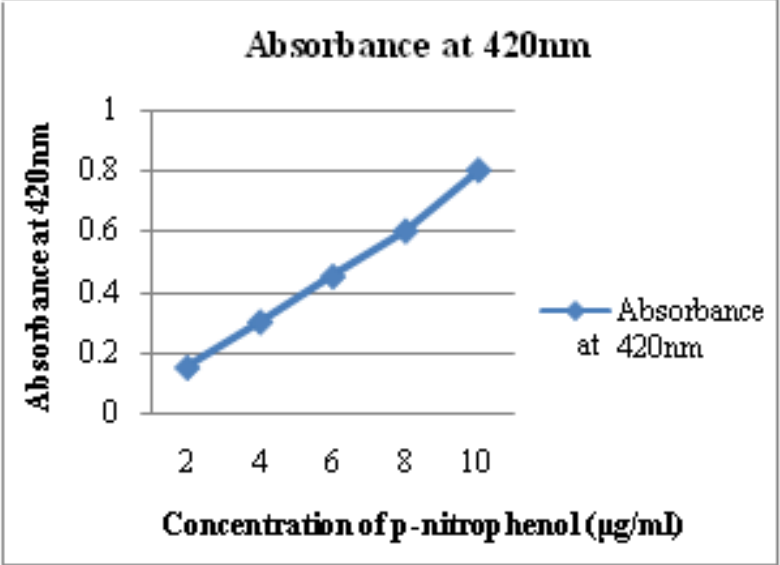

Figure 1: Standard curve of P-nitrophenol in alkaline medium at $420 \mathrm{~nm}$

Table 2: Effect of different concentrations of malathion on alkaline phosphatase activity of soil microbes during different periods of time

\begin{tabular}{|c|c|c|c|c|}
\hline & \multicolumn{4}{|c|}{ dose of the pesticide } \\
\hline$\frac{\text { days } \downarrow}{\text { Amt. } \rightarrow}$ & $\begin{array}{c}\text { control } \\
(\mu \mathrm{g} / \mathrm{g} / \mathrm{hr})\end{array}$ & $\begin{array}{c}\text { Recommended } \\
(\mu \mathrm{g} / \mathrm{g} / \mathrm{hr})\end{array}$ & $\begin{array}{l}\text { 2times diluted } \\
(\mu \mathrm{g} / \mathrm{g} / \mathrm{hr})\end{array}$ & $\begin{array}{c}\text { 5times diluted } \\
(\mu \mathrm{g} / \mathrm{g} / \mathrm{hr})\end{array}$ \\
\hline Ohr & 6.899 & 7.374 & 6.498 & 5.044 \\
\hline S.D. & 0.113 & 0.044 & 0.029 & 0.034 \\
\hline $3^{\text {rd }}$ day & 7.695 & 10.383 & 9.999 & 9.704 \\
\hline S.D. & 0.119 & 0.004 & 0.010 & 0.004 \\
\hline $7^{\text {th }}$ day & 0.025 & 0.072 & 0.141 & 0.129 \\
\hline S.D. & 0.008 & 0.024 & 0.047 & 0.143 \\
\hline $10^{\text {th }}$ day & 0.319 & 0.569 & 0.202 & 0.397 \\
\hline S.D. & 0.059 & 0.223 & 0.048 & 0.008 \\
\hline
\end{tabular}

Amt. = amount of p-nitrophenol $(\mu \mathrm{g} / \mathrm{g} / \mathrm{hr})$

S.D. = standard deviation of amount of p-nitrophenol $(\mu \mathrm{g} / \mathrm{g} / \mathrm{hr})$

\subsection{Acid phosphatase activity of malathion treated soil}

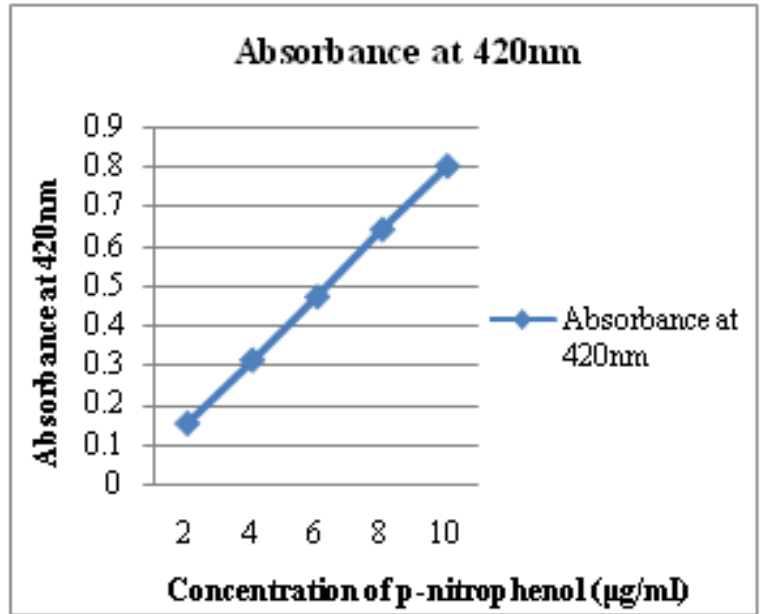

Figure 2: Standard curve of P-nitrophenol in acidic medium at $420 \mathrm{~nm}$

Table 3: Effect of different concentrations of malathion on acid phosphatase activity of soil microbes during different periods of time

\begin{tabular}{|c|c|c|c|c|}
\hline & \multicolumn{4}{|c|}{ dose of the pesticide } \\
\cline { 1 - 4 } days $\downarrow$ & $\begin{array}{c}\text { control } \\
(\mu \mathrm{g} / \mathrm{g} / \mathrm{hr})\end{array}$ & $\begin{array}{c}\text { Recommended } \\
(\mu \mathrm{g} / \mathrm{g} / \mathrm{hr})\end{array}$ & $\begin{array}{c}\text { 2times diluted } \\
(\mu \mathrm{g} / \mathrm{g} / \mathrm{hr})\end{array}$ & $\begin{array}{c}\text { 5times diluted } \\
(\mu \mathrm{g} / \mathrm{g} / \mathrm{hr})\end{array}$ \\
\cline { 1 - 4 } Amt. $\rightarrow$ & 80.878 & 94.571 & 78.46 & 109.352 \\
\hline S.D. & 0.268 & 0.313 & 0.222 & 0.911 \\
\hline $3^{\text {rd }}$ day & 121.174 & 195.251 & 181.897 & 189.897 \\
\hline S.D. & 0.251 & 0.956 & 0.332 & 39.433 \\
\hline $7^{\text {th }}$ day & 10.359 & 15.263 & 14.441 & 10.144 \\
\hline S.D. & 0.055 & 0.246 & 0.173 & 4.741 \\
\hline $10^{\text {th }}$ day & 2.329 & 7.693 & 7.373 & 5.974 \\
\hline S.D. & 0.246 & 0.019 & 0.112 & 0.304 \\
\hline
\end{tabular}

Amt. = amount of p-nitrophenol $(\mu \mathrm{g} / \mathrm{g} / \mathrm{hr})$ 


\section{International Journal of Science and Research (IJSR) \\ ISSN (Online): 2319-7064 \\ Index Copernicus Value (2013): 6.14 | Impact Factor (2014): 5.611}

S.D. = standard deviation of amount of p-nitrophenol $(\mu \mathrm{g} / \mathrm{g} / \mathrm{hr})$

\section{Conclusion}

The widespread agricultural use of pesticides resulted in these chemicals entering soil and water ecosystems [19]. Pesticides applied to soil at planting persist during the development of plant roots. Therefore, a portion of the pesticide likely interacts with microorganisms in soil and rhizosphere [20].

The use of pesticides in minimum effective doses may be beneficial but due to unjustifiable use their harmful effects have become manifold and far reaching. Sadly, chemical pesticides still continue to be used in large proportions in many parts of the world which interfere with the soilmicrobe and soil-enzyme interactions, ultimately leading to environmental degradation. As such, it is hoped that this work and its results will be beneficial to the agricultural communities and thereby encourage them to switch to less toxic or biological alternatives for our own wellbeing.

\section{Acknowledgement}

The author is thankful to the principal of Sibsagar Girls' College, Dr. L.M. Borchetia for her keen interest in this research work. The author is also grateful to the coordinator of the Institutional Level Biotech Hub of Sibsagar Girls' College, Dr. B. Dutta for providing all chemicals and other expenses.

\section{References}

[1] M.R. Bonner, J. Coble, A. Blair, et al., "Malathion Exposure and the Incidence of Cancer in the Agricultural Health Study," American Journal of Epidemiology, CLXVI (9), pp. 1023-1034, 2007.

[2] C.D.S. Tomlin, The pesticide manual, 14th Ed., World compendium, British Crop Production Council (BCPC), Alton, Hampshire, 2006.

[3] M.J. Pelczar, Jr., E.C.S. Chan, N.R. Krieg, Microbiology, McGraw Hill Education, 2014.

[4] J. Gonzalez-Lopez, M.V. Martinez-Toledo, B. Rodelas, V. Salmeron, "Studies on the effects of the insecticides, phorate and malathion, on soil microorganisms," Env. Toxic. Chem., XII (7), pp. 1209-1214, 1993.

[5] M. Digrak, F. Kazanici, "Effect of some organophosphorus insecticides on soil microorganisms," Turk. J. Biol., XXV, pp. 51-58, 2001.

[6] L. Mandic, D. Dukic, M. Govedarica, S. Stamenkovic, "The effect of some insecticides on the number of amylolytic microorganism and azotobacters in apple nursery soil," Jug. Voc., XXXI (2), pp. 177-184, 1997.

[7] A.M. Haleem, S.A. Kasim, J.A. Al-Timimy, "Effect of some organophosphorus insecticides on soil microorganisms populations under lab condition," World Environment., III (5), pp. 170-173, 2013.

[8] A.C. Das, A. Chakravarty, P. Sukul, D. Mukherjee, "Influence and persistence of phorate and Carbofuran insecticides on microorganisms in rice field," Chemosphere, LIII, pp. 1033-1037, 2003.
[9] F.F. Wu, A. Stachyra, D. Vilglierchio, "The capacity of soil microbial isolates from non-fumigant nematicide stressed Heterodera schachtii greenhouse culture stocks to inactivate non-fumigant nematicides," Fundam. Appl. NemalOl., XV (3), pp. 193-200, 1991.

[10] S. Dordevic, M. Sestovic, V. Raicevic, A. Dordevic, "Fluctuation of the abundance of microorganisms in the carbofuran treated soil," Pest, XIII (4), pp. 281-288, 1998.

[11]A.C. Das, D. Mukherjee, "Insecticidal effects on soil microorganisms and their biochemical processes related to soil fertility," World J. Microbio., XIV (6), pp. 903906, 1998.

[12]B. Dehingia, B.K. Dutta, "A case study on the effect of pesticides on soil microbial enzymes: alkaline phosphatase and nitrate reductase," Journal of Frontline Research in Arts and Science, II, pp. 128-133, 2012.

[13] K.Y. Kim, D. Jordan, G. A. McDonald, "Effect of phosphate-solubilizing bacteria and vesicular-arbuscular mycorrhizae on tomato growth and soil microbial activity,” Biol. Fert. Soils XXVI, pp. 79-87, 1998.

[14]G.R. Chaudhry, W.B. Wheeler, "Biodegradation of carbamates," Wat Sci Tech, XX, pp. 89-94, 1988.

[15] K.D. Racke, J.R. Coats, "Comparative degradation of organophosphorus insecticides in soil: Specificity of enhanced microbial degradation," J Agric Food Chem XXXVI, pp. 193-199, 1988.

[16]K. Ramanad, M. Sharmila, N. Sethunathan, "Mineralization of carbofuran by soil bacterium," Appl Environ Microbiol, LIV, pp. 2129-2133, 1988.

[17] J.G. Edwards, "DDT: A case study in scientific fraud," Journal of American Physicians and Surgeons, XI (3), pp. 83-88, 2004.

[18]T.M.A. Thabit, M.A.H. El-Naggar, "Malathion degradation by soil isolated bacteria and detection of degradation products by GC-MS," International Journal of Environmental Sciences, III (5), pp. 1467-1476, 2013.

[19] I.R. Hill, S.J.L. Wright (Eds), Pesticide microbiology, Academic Press, London, p. 586, 1978.

[20] M.A. Wootton, R.J. Kremer, A. Keaster, "Effects of carbofuran and the corn rhizosphere on growth of soil microorganisms," Bull Environ Contam Toxicol, L, pp. 49-56, 1993.

\section{Author Profile}

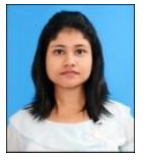

Bonita Mahanta received the BSc degree in Botany and the MSc degree in Life Sciences from Dibrugarh University in 2013 and 2015 respectively. During 2013-15, she studied the effect of several pesticides on the nitrate reductase, alkaline phosphatase and acid phosphatase activity of soil microbes. She is currently serving as a junior research fellow at Institutional Level Biotech Hub, Sibsagar Girls' College, Sivasagar. 